\title{
The Effectiveness of Rice Straw Based Compost on Potato Production as a Basis of Organic Farming System in North Sulawesi Indonesia
}

\author{
Herlina N. Salamba ${ }^{1, *}$, Ibrahim Erik Malia ${ }^{1}$, and Miftahulhair Ardan $^{1}$ \\ ${ }^{1}$ North Sulawesi Assessment Institute for Agricultural Technology (AIAT), Jl. Kalasey Agriculture \\ Campus
}

\begin{abstract}
An experiment to observe the influence of compost by rice straw in potato production has been conducted in North Sulawesi from April to October 2015. Therefore this research was conducted with the objectives: (1) to find out the effects of rice straw-based compost compared to manure on potato production; and (2) to ensure the use of compost without inorganic fertilizer in the potato-based farming system as a basis of organic farming system in the production center of potato in Western Indonesia. The treatments were designed into CRBD proceeded to the Least Significant Difference Test (LSD test). Six treatments were applied, $\mathrm{A}=$ Compost 20 t.ha $^{-1}$ plus inorganic fertilizer; $\mathrm{B}=$ Manure 20 tha ${ }^{-1}$ plus inorganic fertilizer; $\mathrm{C}=$ Compost 20 th ha $^{-1}$ without inorganic fertilizer; $\mathrm{D}=$ Compost 12 t.ha $^{-1}$ plus inorganic fertilizer $\mathrm{E}=$ Compost 12 t.ha $^{-1}$ without inorganic fertilizer and $\mathrm{F}=$ Manure 5 tha $^{-1}$ plus inorganic fertilizer. Parameters tested show that the treatments of compost have advantages compared with the manure treatment. This related to the nutrients composition of straw rich especially potassium. Treatment A (Compost 20 t.ha $^{-1}+$ inorganic fertilizers) is not significantly different from treatment C compost 20 t.ha $^{-1}$ without inorganic fertilizers) in almost parameters except tuber weight of Grade \#1 (industry purposes), describing the potency of the organic agricultural system of potato by using compost rice straw based. However, the organic agricultural system economically could be applied by the farmer as well as ease to get the materials. It also provides sustainable agricultural practices in the production center of a potato.
\end{abstract}

\section{Introduction}

Modoinding, the Horticulture Development Zone in the district of South Minahasa lies at an altitude of about 1,000-1,200 $\mathrm{m}$ above sea level with an area of 6,640 ha [1]. The area has isothermal temperature regimes (cool) and included in the zone IIIbx (III = indicates altitude $>700 \mathrm{~m}$ asl. $\mathrm{B}=$ cool temperatures and moist; $\mathrm{x}=$ physiographic and vegetation types in). Dominated by soils derived from volcanic ash, among others Andosol, Inceptisol, and Alfisol and Oxisol [2]. This area is the main vegetable production center located in the

\footnotetext{
* Corresponding Author: nanny.2231@gmail.com
} 
eastern part of Indonesia. One of the major commodities is potatoes. The growing acreage of potato in the area is 2,970 ha [3]. This productivity is still below the national productivity of 7.16 th.ha $^{-1}$ [4], and far below potential according to the research, as stated by [5] that the potatoes productivity with improved varieties and balanced fertilization can reach 52 t.ha ${ }^{-1}$. Besides the low productivity, the quality is very important to be improved to face global competition due to unlike Mexico who has an importing barrier by applying a duty of $245 \%$ applied to imports from countries beyond North American Countries [6],

The low yield of potatoes in Indonesia is not only caused by the use of low-quality seeds and varieties that produce low, but also by farming techniques that are less good, less precise control of pests and diseases, and lack of knowledge of farmers on an appropriate fertilization method [7]. Another problem is not the optimal use of organic materials available at the farm level, including rice straw in the village surrounding the development of horticulture is. However, proper nutrition is crucial in determining potato yield and quality, as well as potato plant's ability to withstand pest, environmental, and other stresses [8]. This statement is supported by [9] stating that nutrient management is a controllable input that potato growers utilize to ensure high tuber yields and quality, furthermore, both $\mathrm{N}$ and $\mathrm{K}$ fertilization are often required for maximum production.

In the production center of North Sulawesi the farmer is difficult to apply an appropriate and balanced fertilizer, besides the knowledge limitations, it is also caused by the inaccessible of the sources of the fertilizer. Since 2007, the $\mathrm{KCl}$ as $\mathrm{K}$ fertilizer's main commercial formulation was increased significantly up to 3 times due to the government policy by reducing subsidy, as a result, the most farmer stopped use this fertilizer. Moreover, the same farmer substitute $\mathrm{K}$ fertilizer by non-K sources such as SP-36 or Urea bringing about excessive use of $\mathrm{P}$ and N. Meanwhile, they reduce all biomass from the farm. After the harvest the tuber, they burn the rest plant components like roots, stems, and leaves. Removing the organic matter from the farm may causes problems, not only on soil fertility but also on soil structure. [11] stated that organic matter as aggregate soil conditioner can withstand and improve soil physic supported by soil organisms using it as energy sources. Therefore, aside from being a source of organic nutrients, compost plays an important role in the improvement of soil structure, so the aeration air and water movement smoothly, thus can increase the absorption of water in the soil and improve plant growth and production $[11,12]$ also, to be a cheaper alternative to improve soil fertility improves the efficiency of fertilization, soil productivity, and reduce the danger of environmental pollution [13].

The sources of organic material that have a lot of potential are wasted rice straw and manure. The use of rice straw compost on potatoes cultivation could potentially increase productivity while improving the quality of the product that has been highly dependent on chemical inputs. Economically, the use of compost will be very positive because of a high $\mathrm{K}$ content of potentially substituting $\mathrm{K}$ commercial sources such a $\mathrm{KCl}$ which was very expensive at the farm level. Then, the compost application can automatically reduce the pesticide application. A research conducted by [14] in West Java, another potato production center in Indonesia, gained that after applying integrated organic farming reduce pesticide concentration from $9.85 \mathrm{ppb}$ (first year) to $7.97 \mathrm{ppb}$ (second year) due to the reducing of agrochemical application. Therefore this research was conducted with the objectives: (1) to find out the effects of rice straw-based compost compared to manure on potato production; and (2) to ensure the use of compost without inorganic fertilizer in the potato-based farming system as a basis of organic farming system in the production center of potato in Western Indonesia.

\section{Materials and Materials}

Pre experiment was conducted to survey get the farming practices information in the region. 
The survey was done before the field experiment. There are 200 participants interviewed by using purposive sampling addressed directly to the farmer cultivating potato at least in the last 5 years. Data collecting in the pre-experiment were fertilizer, insecticide, and fungicide application. The experiment was conducted in April to October 2015 on a potato production center in Modoinding, North Sulawesi. The altitude of $1110 \mathrm{~m}$ above sea level, wherein the soil is classified as Andisols. The variety of potato used was Super John, a local high yielding variety. This variety is used by more than $80 \%$ of the farmers in this region due to its high productivity. The size of the seeds is $28-55 \mathrm{~mm}$ weighing between $40-60 \mathrm{~g}$ per tuber and planted after sprouting. Planting is conducted within prepared seedbed, the spacing of $75 \mathrm{~cm} \times 30 \mathrm{~cm}$. Therefore, the populations are about 44,000 plants.ha ${ }^{-1}$. The tubers were sowed within a depth of $7-10 \mathrm{~cm}$. This population is considered as appropriately agronomical standard, as supported by the study of [15] conducted in the Klamath Basin of Oregon with Russet Norkotah, which found no significant difference in total or U.S. No.1 yields for a plant population range of 41,152 to 72,621 plants.ha ${ }^{-1}$. However, the area of each plot is $10 \mathrm{~m} \times 10 \mathrm{~m}$.

The design used was a Completely Randomized Block Design. Then the Least Significant Difference Test (LSD) was used for mean separations. Significantly, was determined at the $p=0.05$ probability level. The experiment consists of 6 treatments and 5 replications. The treatments were:

$\mathrm{A}=$ Compost 20 t.ha $^{-1}+$ inorganic fertilizers;

$\mathrm{B}=$ Manure 20 t.ha $^{-1}+$ inorganic fertilizer

$\mathrm{C}=$ compost 20 t.ha ${ }^{-1}$ without inorganic fertilizers;

$\mathrm{D}=$ Compost $12 \mathrm{t} \cdot \mathrm{ha}^{-1}+$ inorganic fertilizers;

$\mathrm{E}=$ Compost 12 t.ha $^{-1}$ without inorganic fertilizers

$\mathrm{F}=$ Manure $5 \mathrm{t}^{\mathrm{h} \mathrm{ha}^{-1}}+$ inorganic fertilizer, representing the average local farmer practices.

All inorganic fertilizer use recommendation from Research Institute for Vegetables (Vegetable Research Institute), namely, $180 \mathrm{~kg} \mathrm{~N}, 92 \mathrm{~kg} \mathrm{P} 2 \mathrm{O} 5$ and $150 \mathrm{~K} 2 \mathrm{O}$ [16]. Application of organic fertilizers given before planting, mixed with soil. Then, all treatments to use inorganic fertilizer were given twice. Firstly, in the planting time, the entire $\mathrm{P}$ and $\mathrm{K}$ and a half dosage of $\mathrm{N}$ were applied. The next fertilization time at age 35 days to give half dosage of N. Fertilization is conducted by sown it into prepared holes with a distance from the nearest plant about $5-7 \mathrm{~cm}$ in the first application and $10-12 \mathrm{~cm}$ in the second application.

The parameters measured were the plant height, the number, and weight of tubers per plant. Each plot was observed 10 plants were randomly determined on plants beyond the border plants. Weight of tuber is classified into five classes, namely:

Grade \# 1 = tubers weight $>200 \mathrm{~g}$ per item, the industry purposes

Grade \# 2 = tubers weight $60 \mathrm{~g}-199 \mathrm{~g}$ per item, vegetable/consumption purposes

Grade \# 3 = tubers weight $40 \mathrm{~g}-60 \mathrm{~g}$ per item, the seed purposes

Grade \# 4 = tubers weight $20 \mathrm{~g}-40 \mathrm{~g}$ per item, the seed reserve purposes

Grade \# 5 = tubers weight $<20$ g per item, tubers rejected.

\section{Results and Discussion}

\subsection{Pre experiment}

The potato's farmer custom on farming was identified before the field experiment. As shown in Table 1, the unbalanced fertilizer applications are continuously done in the last 5 years. No farmer apply balance fertilizer as recommended by any research or extension 
institute. Before 2006, the farmer using NPK was still above $60 \%$, but it became worse in 2007 due to the government policy stopping the potassium fertilizer subsidy brought about an increase in price at the farmer level. Therefore, The farmer committed to using cheaper fertilizer. However, they do not have enough knowledge to decide the fertilizer composition. As a result, they use excessive $\mathrm{N}$ and P. Some farmers use Urea more than $600 \mathrm{~kg} \cdot \mathrm{ha}^{-1}$, even it was found that 3 farmers use SP-36 up to $900 \mathrm{~kg} \cdot \mathrm{ha}^{-1}$. The Indonesian government has distributed NPK compounds, hence, the farmer started to use it in 2007 and increase gradually in the next years.

Table 1. Application of fertilizer on Potato by the farmer in Modoinding, production center of North Sulawesi

\begin{tabular}{|l|c|c|c|c|c|}
\hline \multirow{2}{*}{ Treatment } & \multicolumn{5}{c|}{ Year } \\
\cline { 2 - 6 } & $\mathbf{2 0 1 0}$ & $\mathbf{2 0 1 1}$ & $\mathbf{2 0 1 2}$ & $\mathbf{2 0 1 3}$ & $\mathbf{2 0 1 4}$ \\
\hline Balanced & - & - & - & - & - \\
\hline Complete (NPK) & 63 & 61 & 17 & 23 & 42 \\
\hline N only & 12 & 8 & 8 & 25 & 24 \\
\hline P only & 0 & 0 & 0 & 0 & 0 \\
\hline K only & 0 & 0 & 0 & 0 & 0 \\
\hline Access N & 68 & 68 & 68 & 82 & 82 \\
\hline Access P & 45 & 45 & 62 & 72 & 72 \\
\hline Access K & 0 & 0 & 0 & 0 & 0 \\
\hline NP only & 25 & 32 & 75 & 52 & 34 \\
\hline & & & & & \\
\hline NPK Compounds & 0 & 0 & 17 & 23 & 42 \\
\hline
\end{tabular}

Source: primary data collected by 200 potato farmers representing the production center area.

\subsection{Plant Height}

Plant height is an indicator of the vegetative growth of a plant despite it is not automatically correlated to the generative product like grain, tuber, etc. In this experiment, the plant height of potato was not different among the 6 treatment until 5 WAP. In 6 WAP, the treatments contained inorganic (treatment $\mathrm{B}$ and F) were quite different and higher than the treatment without inorganic. It indicates that the inorganic fertilizer influence the plant height of potato but as it was shown in Table 3 and Table 4, there is no difference between the inorganic and without inorganic treatment on tuber production.

Table 2. Plant height of potatoes on several levels of organic fertilizer in Modoinding, production center of North Sulawesi, 2010.

\begin{tabular}{|c|l|l|l|l|l|l|}
\hline \multirow{2}{*}{ Treatment } & \multicolumn{7}{|c|}{ Plant Height (cm) } \\
\cline { 2 - 7 } & 3 WAP & 4 WAP & 5 WAP & 6 WAP & 7 WAP & 9 WAP \\
\hline A & $7.24 \mathrm{a}$ & $15.20 \mathrm{a}$ & $23.50 \mathrm{a}$ & $40.35 \mathrm{ab}$ & $56.21 \mathrm{a}$ & $66.70 \mathrm{~b}$ \\
\hline $\mathrm{B}$ & $7.01 \mathrm{a}$ & $14.12 \mathrm{a}$ & $25.33 \mathrm{a}$ & $41.21 \mathrm{a}$ & $56.67 \mathrm{a}$ & $68.25 \mathrm{ab}$ \\
\hline $\mathrm{C}$ & $6.95 \mathrm{a}$ & $15.08 \mathrm{a}$ & $22.97 \mathrm{a}$ & $38.98 \mathrm{~b}$ & $52.12 \mathrm{~b}$ & $63.25 \mathrm{bc}$ \\
\hline $\mathrm{D}$ & $7.07 \mathrm{a}$ & $16.13 \mathrm{a}$ & $24.43 \mathrm{a}$ & $40.57 \mathrm{ab}$ & $53.67 \mathrm{ab}$ & $65.89 \mathrm{~b}$ \\
\hline $\mathrm{E}$ & $6.82 \mathrm{a}$ & $14.88 \mathrm{a}$ & $23.01 \mathrm{a}$ & $39.14 \mathrm{~b}$ & $52.89 \mathrm{~b}$ & $62.56 \mathrm{c}$ \\
\hline F & $7.31 \mathrm{a}$ & $15.22 \mathrm{a}$ & $25.03 \mathrm{a}$ & $42.33 \mathrm{a}$ & $57.17 \mathrm{a}$ & $67.28 \mathrm{a}$ \\
\hline
\end{tabular}

Notes: The numbers followed by the same letter in the same column are not significantly different in the 5\% LSD test.

\subsection{Tuber Production}

The results showed that the production of tubers from the compost treatment is the goal of 
the research is higher than the other treatments (Table 3 and Table 4). By the six treatments, the two parameters, namely, the number of tubers /plant and tuber weight/plant and then observed in 5 grade (A, B, C, D, E) show the advantages of treatment containing compost 20 t.ha $^{-1}$ both with or without inorganic fertilizer compared with other treatments.

The comparison between the treatment of substance use rice straw compost, manure, and inorganic fertilizer is interesting to discuss where the influence of compost on potato tuber production significantly different from the effect of combinations of manure and inorganic fertilizer $\mathrm{N}, \mathrm{P}$, and $\mathrm{K}$. Grading is done due to the farming perspective on the market. Grade \#1 (weight> $200 \mathrm{~g} /$ tuber) is designated as industrial raw materials such as French fries, crispy, and so on. Treatment $\mathrm{A}=$ compost $20 \mathrm{t} \cdot \mathrm{h}^{-1}+$ inorganic fertilizer shows that tuber Grade A produced the highest and significantly different manure treatment with the same dosage (treatment B). In Table 1, is shown that tuber number Grade \#1 in the treatment $\mathrm{A}$ is $1.76(8.4 \%)$, while only $0.8(3.6 \%)$ in treatment $\mathrm{B}$. Then, on Grade \#2 (weight 60-199 g/ tuber) compost treatments are also better and significantly different from manure treatments. The number of tuber Grade \#2 by compost treatment A is 10:48 $(50.1 \%)$, higher and significantly different with manure treatment $\mathrm{B}$, even not only in treatment $\mathrm{A}$ but treatment $\mathrm{C}=$ compost $20 \mathrm{t}$. ha ${ }^{-1}$ without inorganic fertilizers $10.5(51.2 \%)$, treatment $\mathrm{D}=$ compost 12 t.ha $^{-1}+$ inorganic fertilizers 10:48 $(48.9 \%)$ even in the treatment $\mathrm{E}=$ compost 12 t.ha ${ }^{-1}$ without inorganic fertilizers $8.2(46.1 \%)$ did not differ significantly with treatment B 9:38 (42.2\%). Then, by tubers Grade \#3, the perspectives for the seed tubers were not significantly different between the treatments of compost and manure. Only treatment $\mathrm{E}$ tubers for seed production are significantly different from other treatments. However, the number of seeds Grade \#4 which can be reserved as a backup if the local seed development seed shortfall Grade \#3 high enough on the E treatment.

Table 3. The results of the tuber number of potatoes on several levels of organic fertilizer in Modoinding, North Sulawesi, in 2010.

\begin{tabular}{|c|c|c|c|c|c|c|r|r|r|r|r|}
\hline \multirow{2}{*}{$\begin{array}{c}\text { Treat } \\
\text { ment }\end{array}$} & \multicolumn{2}{|c|}{ Grade \# } & \multicolumn{2}{|c|}{ Grade \# 2 } & \multicolumn{2}{c|}{ Grade \# 3 } & \multicolumn{2}{c|}{ Grade \# 4 } & \multicolumn{2}{c|}{ Grade \# 5 } & amount / \\
\cline { 2 - 12 } & Amount & \% & amount & \% & amount & \% & amount & \% & amount & \% & plant \\
\hline A & $1.76 \mathrm{a}$ & 8.4 & $10.48 \mathrm{a}$ & 50.1 & $2.74 \mathrm{abc}$ & 13.1 & $3.06 \mathrm{~b}$ & 14.6 & $2.90 \mathrm{~b}$ & 13.9 & 20.94 \\
\hline $\mathrm{B}$ & $0.80 \mathrm{c}$ & 3.60 & $9.38 \mathrm{ab}$ & 42.2 & $3.80 \mathrm{a}$ & 17.1 & $4.68 \mathrm{a}$ & 21.1 & $3.56 \mathrm{ab}$ & 16.0 & 22.22 \\
\hline $\mathrm{C}$ & $1.52 \mathrm{a}$ & 7.32 & $10.50 \mathrm{a}$ & 51.2 & $2.52 \mathrm{abc}$ & 12.3 & $3.08 \mathrm{~b}$ & 15.0 & $2.90 \mathrm{~b}$ & 14.2 & 20.50 \\
\hline $\mathrm{D}$ & $0.40 \mathrm{~d}$ & 1.87 & $10.48 \mathrm{a}$ & 48.9 & $3.56 \mathrm{ab}$ & 16.6 & $3.26 \mathrm{~b}$ & 15.2 & $3.74 \mathrm{ab}$ & 17.4 & 21.44 \\
\hline $\mathrm{E}$ & $1.20 \mathrm{ab}$ & 6.74 & $8.20 \mathrm{~b}$ & 46.1 & $1.90 \mathrm{c}$ & 10.7 & $3.80 \mathrm{ab}$ & 21.4 & $2.70 \mathrm{~b}$ & 15.2 & 17.80 \\
\hline F & $0.16 \mathrm{~d}$ & 0.99 & $6.28 \mathrm{c}$ & 38.7 & $2.22 \mathrm{bc}$ & 13.7 & $3.32 \mathrm{ab}$ & 20.5 & $4.24 \mathrm{a}$ & 26.1 & 16.22 \\
\hline
\end{tabular}

Notes: The numbers followed by the same letter in the same column are not significantly different in the $5 \%$ LSD test.

The results of the tuber's weight per plant are shown in Table 4. The advantages of the rice straw-based compost treatments are clearly shown on tuber production Grade \#1 and Grade \#2. However, Grade \#1 products are considered as industrial purposes, while tuber Grade \#2 is mostly for fresh consumption as a vegetable as well as staple substitution. The weight of Treatment A, Grade \#1 is $447 \mathrm{~g}$ per plant different from treatment B Grade \#1 only has $200 \mathrm{~g}$ per plant. Furthermore, the advantage of using compost shown more on treatment $\mathrm{C}$, the full treatment of $20 \mathrm{t}^{-h^{-1}} \mathrm{c}^{-}$compost without inorganic fertilizer resulting tuber $327 \mathrm{~g} /$ plant, even it is significantly different from treatment $\mathrm{B}$, the manure+inorganic treatment resulted.

For the Grade \#2, the consumption purposes of potato tuber, however, it is still dominated by the compost treatment (treatment $\mathrm{A}$, treatment $\mathrm{C}$, and treatment $\mathrm{D}$ ) resulting 1242,1229 , and $1041 \mathrm{~g}$ per plant successively, compared to treatment B resulting only 878 g per plant. 
Table 4. The results of the tuber weight of potatoes on several levels of organic fertilizer in Modoinding, North Sulawesi, in 2010.

\begin{tabular}{|c|r|r|l|l|l|l|}
\hline \multirow{2}{*}{ Treatment } & \multicolumn{7}{|c|}{ Tuber weight per plant (g) } \\
\cline { 2 - 7 } & Grade \# 1 & Grade \# 2 & Grade \# 3 & Grade \# 4 & Grade \# 5 & Total \\
\hline A & $447 \mathrm{a}$ & $1242 \mathrm{a}$ & $139 \mathrm{abc}$ & $93 \mathrm{~b}$ & $44 \mathrm{a}$ & $1965 \mathrm{a}$ \\
\hline $\mathrm{B}$ & $200 \mathrm{c}$ & $878 \mathrm{~b}$ & $190 \mathrm{a}$ & $134 \mathrm{a}$ & $37 \mathrm{a}$ & $1439 \mathrm{~b}$ \\
\hline $\mathrm{C}$ & $317 \mathrm{~b}$ & $1229 \mathrm{a}$ & $131 \mathrm{abc}$ & $91 \mathrm{~b}$ & $38 \mathrm{a}$ & $1806 \mathrm{a}$ \\
\hline $\mathrm{D}$ & $83 \mathrm{~d}$ & $1041 \mathrm{ab}$ & $173 \mathrm{ab}$ & $93 \mathrm{~b}$ & $30 \mathrm{a}$ & $1421 \mathrm{~b}$ \\
\hline $\mathrm{E}$ & $262 \mathrm{~b}$ & $809 \mathrm{~b}$ & $93 \mathrm{c}$ & $108 \mathrm{ab}$ & $27 \mathrm{a}$ & $1299 \mathrm{~b}$ \\
\hline F & $39 \mathrm{~d}$ & $563 \mathrm{c}$ & $108 \mathrm{bc}$ & $91 \mathrm{~b}$ & $42 \mathrm{a}$ & $843 \mathrm{c}$ \\
\hline
\end{tabular}

Notes: The numbers followed by the same letter in the same column are not significantly different in the $5 \%$ LSD test.

The positive values of the treatments of rice straw compost ingredients are consistent with some previous researches. The nutrient content of rice straw is different from the nutrient elements of manure, where the composition of rice straw is $1.08 \% \mathrm{~N}$-total, P-total $0.17 \%$, K-total $2.70 \%$ while the nutrient of manure content is $\mathrm{N}=1,81 \%, \mathrm{P} 0205=1.89 \%$ and $\mathrm{K} 20=1.96 \%$ [17].

The real difference is the high content of $\mathrm{K}$ in straw compost material. This is also supported by the research conducted by [18], who stated that the rice straw is a good source of Potassium (K) and Silicate (Si), approximately $80 \%$ of $\mathrm{K}$ absorbed by plants is stored in its hay. Potassium is required in high amounts by potatoes, due to their relatively poorly developed root system [19]. It is also supported by others statement that potassium and nitrogen are found in the largest amounts in a potato plant, followed by $\mathrm{Ca}$ and $\mathrm{Mg}$ [20], therefore, fertilizer $\mathrm{K}$ applications are often required for optimum potato yield [21].

$\mathrm{K}$ fertilizer is very suitable in organic forms such as compost because giving through inorganic fertilizers without organic soil, C-balance to negative effect. The concentration of $\mathrm{K}$ in the soil with inorganic fertilizer on barley can reduce the concentration of $\mathrm{Ca}$ in the shoots and roots of the plants. Furthermore [22], [23] suggested that the balance of nutrient elements, especially $\mathrm{K}$ in the soil plays an important role in the synthesis of carbohydrates and protein. Potassium also plays an important role in potato protection. An experiment conducted in Kimberly, Idaho, the USA by [24] resulted that a compost treatment significantly increased production of large tubers compared to inorganic $\mathrm{P}$ fertilizer.

Furthermore, [25] stated that the increased C-organic content of 1\% increase in water content provided by $2 \%$. In this experiment, this correlates with the high production of potato tubers in compost treatment, although research conducted in the dry season. Conversely, the reduced content of C-organic soil can cause soil degradation can affect microbiology communities in soil [26]. Also, organic materials can improve the water holding capacity of the soil. In agricultural practices, the high content of organic matter can simplify tillage and can protect the soil from surface erosion [27].

Another research on tomato, showing an application of compost on the plant also showed an advantage of compost over the use of manure conducted by [28], resulting the percentage increase in weight of the tomatoes by the treatment of rice straw compost is $64.5 \%$ igher than the chicken manure resulting increase in weight is $58.8 \%$.

The use of rice straw compost in an economic perspective is potentially developed. Tuber yield was presented in Table 1 and Table 2, indicating that the use of compost as a substitute for inorganic fertilizer especially $\mathrm{K}$ is very promising. $\mathrm{K}$ fertilizer price is very expensive; therefore, it is not affordable by the farmers. These cause the potato farmers in North Sulawesi to mostly do not use fertilizer containing K so that in addition to low crop productivity as well as nutrient imbalance in the soil. Treatment compost 20 t.ha $^{-1}+$ inorganic fertilizer was not significantly different with the same amount of compost treatment but without inorganic fertilizers on almost all parameters except the weight of 
tuber Grade A. Even at Grade D parameters, namely seed tubers perspective, treatment E compost 12 t.ha $^{-1}$ without either inorganic fertilizer higher number of tubers and weight compared to a maximum of compost + inorganic fertilizers treatment. Therefore, it economically does not need to give additional inorganic materials. The results can be acted upon as the basis for the application of organic farming using potato commodity in North Sulawesi by using compost without inorganic fertilizers.

\section{Conclusion and Recommendation}

\subsection{Conclusion}

Organic fertilizer formulated by rice straw-based compost can increase potato production and comparatively better than other sources of organic materials such as manure. It can substitute the use of inorganic fertilizer which is expensive and sometimes is difficult gotten by the farmer. Therefore, it can be considered as a basis for the application of organic farming system using potato commodity in North Sulawesi. In addition to developed the exclusive region as a vegetable production center, the experimental results lead to healthy products economically benefit and technically easy and sustainable to be practiced. The results can lead to policy maker, mainly local the government to provide policy and to consider the certain area as healty organic vagetable production center.

\subsection{Recommendation}

The dosage of organic fertilizer technically is the best using compost $20 \mathrm{t}^{\mathrm{h} \mathrm{h}^{-1}}$, but since it is not significantly different from the treatment using compost 12 t.ha ${ }^{-1}$, therefore, it is strongly recommended to the farmer to apply this dosage without additional inorganic fertilizer. Also, the application of the organic farming system on the potato will lead to the user of the system on other commodities in the vegetable production center, then, finally, this area gradually becomes the basis of organic agriculture producing safety product and sustainable land.

The government role is very important to disseminate this result to the farmers as well as to promote the organic product to the consumers, traders, and other users.

Acknowledgments. The author would like to thank the Research Institute for Vegetables, Assessment Institute for Agricultural Technology for funding this research. Special thanks for the head of Modoinding Sub-district for giving a permit to do the on-farm research in his place.

\section{References}

1. Badan Statistik Pusat, Minahasa in Figure ( 2017)

2. W. Pasril, Suwandi, T Subagyo, Subandriyo, M Hasanah, E Karmawati. The main results of research to support the development of upland land. Working Meeting II of the Agricultural Research and Development Agency (1998)

3. Statistic Bureau of South Minahasa, South Minahasa in Figures (2019)

4. Silalahi, F.H. J. Hort. 14, 18-22 (1991).

5. Salazar, J.A.G., R.K.Skaggs, and T.L.Crawford, J. American of Potato Research, 8, 411-421 (2012)

6. Statistic Bureau of North Sulawesi. North Sulawesi in Figures (2011)

7. Rosliani, R., N.Sumarni dan Suwandi, J. Horticultura, 81, 988-999 (1998) 
8. Hopkins, B., and J.Stark. Potato Nutrition in Commercial Potato Production in

North America. Second Revision of J. American of Potato .Supplement 57 and USDA Handbook 267 by the Extension Section of the Potato Association of America .p.57-62. (2010)

9. Westermann, D.T., T.A.Tindall, D.W.James, and R.L.Hurst, J. American Potato, 71, 417-431 (2004)

10. N.L, Nurida. and K. Undang, J. Soil and Climate, 30, 37-46 (2009)

11. Widawati, S., Suliasih, dan Syaifudin, J. Biol. Indonesia, 3, 245-253 (2002)

12. Arwan S. dan S.Widawati. J.Biol. Indonesia, 9, 371-378 (2005)

13. S. Saraswati, J. Land Resources, 14 (2007)

14. Indraningsih, Sani, Y and R. Widyastusti. Indonesian J. Agr. Sci., 62 (2005)

15. Rykbost, K.A., and J.Maxwell, J. American of Potato, 70, 463-474 (1993)

16. Nurtika N., E.Sofiari dan G.A.Sopha, J. Horticultural, 183, 267-277 (2008)

17. Indriyati, LT., S. Sabiham, LK. Darusman, R. Situmorang, Sudarsono and WH. Sisworo. J. Soil and Climate, 26, 63-70 (2007)

18. Adiningsih, J. S dan S. Rochayati. The role of organic matter in increasing the efficiency of fertilizer use and soil productivity. In the Proceedings of the National Workshop. Cipayung fertilizer efficiency 16-17 November 1987. Soil Research Center. Agricultural Research and Development Agency. Bogor. p: 161-180.(1988)

19. Perrenoud, S. Fertilizing for Higher Yield Potato. IPI Bull. No.8. $2^{\text {nd }}$ Ed. International Potash Institute, Berne, Switzerland. (1993)

20. Westermann, D.T, J. American of Potato Research, 82, 301-307 (2005)

21. Westermann, D.T., T.A.Tindall, D.W.James, and R.L.Hurst, J. American of Potato, 71,: 417-431 (2004)

22. Johansen, C. D.G. Edwards, and J.F. Loneragan, Plant Physiology, 4310, 1717-1721 (1968)

23. Harison, H.C., E.E.Bergman, and R.H.Cole, J. American of Potato, 593, 113-124 (1982)

24. Moore, A.D., N.L.Olsen, A.M.Carey, and A.B.Leytem., J. American of Potato Research, 88, 324-332 ( 2011)

25. Olness, A.E., and D.W. Archer, Soil Science, 1702, 90-101 (2005).

26. S.O., Peterson and M.J. Klug, Appl. Environ. Microbiol, 60, 2421-2430 ( 1994)

27. Chen, S.S., and T.C. Yung. The effects of organic matter on soil properties. Paper presented at seminar on the use of organic fertilizers in crop production. Suweon, South Korea, (1990)

28. S., Suliasih, S. Widawaty., and A. Muharam, J. Horticulture, 20, 3 (2010) 